\title{
THE ROLE OF THE SOLE EXECUTIVE BODY IN THE ACTIVITIES OF THE CORPORATION
}

\author{
Sergey V. Mudritsky \\ Volgograd Institute of Management - Branch of the Russian Presidential Academy of National Economy \\ and Public Administration, Volgograd, Russian Federation
}

Introduction: consideration of the role of the sole Executive body in the activities of the Corporation is of particular importance in modern conditions of development of corporate relations, since the sole Executive body occupies a dominant place in the system of corporate governance bodies. A Corporation can transfer the functions of a sole Executive body not only to an individual or legal entity, but also to an individual with the status of an individual entrepreneur, since the corresponding prohibition is not contained in the norms of civil legislation. In the event of damage to the Corporation, the sole Executive body may be brought to civil liability. in this regard, the authors set the goal of studying the legal status of the sole Executive body, its rights, duties and responsibilities. Methods: when writing this research, various scientific methods were used, from which we can distinguish historical, comparative legal, formal legal methods, and complex system-structural analysis. Results: the legal position of the sole executive body of the legal entity was studied taking into account recent changes in civil legislation. The author's position on the possibility for an individual entrepreneur to function as an executive body of a legal entity has been substantiated. Conclusions: the study noted imperfection of the legislation regulating the legal status of sole Executive body and the necessity of making a number of changes and additions in normative legal acts.

Key words: corporation, corporate relations, corporate governance, sole Executive body, individual entrepreneur, responsibility.

Citation. Mudritsky S.V. The Role of the Sole Executive Body in the Activities of the Corporation. Legal Concept, 2020, vol. 19, no. 3, pp. 91-96. (in Russian). DOI: https://doi.org/10.15688/lc.jvolsu.2020.3.12

УДК 347.19

Дата поступления статьи: 12.06 .2020

ББК 67.404

Дата принятия статьи: 01.07.2020

\section{РОЛЬ ЕДИНОЛИЧНОГО ИСПОЛНИТЕЛЬНОГО ОРГАНА В ДЕЯТЕЛЬНОСТИ КОРПОРАЦИИ}

\author{
Сергей Васильевич Мудрицкий \\ Волгоградский институт управления - филиал Российской академии народного хозяйства \\ и государственной службы при Президенте РФ, г. Волгоград, Российская Федерация
}

\begin{abstract}
Введение: рассмотрение роли единоличного исполнительного органа в деятельности корпорации представляет особую важность в современных условиях развития корпоративных отношений, поскольку единоличный исполнительный орган занимает главенствующее место в системе органов корпоративного управления. Корпорация может передать функции единоличного исполнительного органа не только физическому и 尺े юридическому лицу, но и физическому лицу в статусе индивидуального предпринимателя, поскольку соответствующего запрета в нормах гражданского законодательства не содержится. В случае причинения вреда корпорации единоличный исполнительный орган может быть привлечен к гражданско-правовой ответственности, в связи с чем в работе поставлена цель - исследование правового статуса единоличного исполнительного органа, его прав, обязанностей и ответственности. Методы: при написании настоящей работы применялись различные научные методы, среди которых можно выделить исторический, сравнительно-правовой, формально-юридический, а также методы комплексного системно-структурного анализа. Результаты: ис() следовано правовое положение единоличного исполнительного органа юридического лица с учетом после-
\end{abstract}


дних изменений в гражданском законодательстве. Обоснована авторская позиция относительно возможности для индивидуального предпринимателя функционировать в качестве исполнительного органа юридического лица. Выводы: в результате исследования отмечено несовершенство действующего законодательства, регламентирующего правовой статус единоличного исполнительного органа, и обоснована необходимость внесения ряда изменений и дополнений в нормативные правовые акты.

Ключевые слова: корпорация, корпоративные отношения, корпоративное управление, единоличный исполнительный орган, индивидуальный предприниматель, ответственность.

Цитирование. Мудрицкий С. В. Роль единоличного исполнительного органа в деятельности корпорации // Legal Concept = Правовая парадигма. - 2020. - Т. 19, № 3. - C. 91-96. - DOI: https://doi.org/10.15688/ lc.jvolsu.2020.3.12

\section{Введение}

Вопрос определения правового статуса единоличного исполнительного органа корпоративной организации является одним из самых дискуссионных и малоизученных в теории уголовного права, но представляет особую важность, поскольку на единоличный исполнительный орган корпоративной организации возлагается основная обязанность по управлению и организации деятельности корпорации, которые могут иметь и негативный эффект для корпорации в виде причиненных убытков, например в результате заключения невыгодной сделки, осуществления необоснованных выплат сотрудникам корпорации и т. д. Неурегулированным является гражданскоправовой статус единоличного исполнительного органа корпоративной организации, например в части оформления с ним трудовых отношений, наделения полномочий, возложения конкретных обязанностей, что также негативным образом сказывается при разрешении споров о возложении ответственности на единоличный исполнительный орган корпоративной организации.

\section{Понятие и положение}

\section{единоличного исполнительного органа}

\section{в системе корпоративного управления}

Юридические лица обладают собственной системой корпоративного управления. Но единоличный исполнительный орган должен быть учрежден в каждом юридическом лице в силу указания положений гражданского законодательства. В учредительных документах юридического лица его участники самостоятельно определяют наименование единоличного исполнительного органа. Никаких ог- раничений в данном вопросе ГК РФ не предусматривает.

Согласимся с мнением И.А. Турбиной в том, что эффективность деятельности юридического лица во многом зависит от умений, профессиональных качеств руководителя организации, правильности организовать работу отдельных подразделений [5, с. 146].

Единоличный исполнительный орган должен исполнять свои обязанности добросовестно, руководствоваться разработанными в корпорации правилами и стандартами поведения, установившимися корпоративной культурой и взаимоотношениями между сотрудниками.

Единоличный исполнительный орган осуществляет волеизъявление корпорации ввиду того обстоятельства, что он воплощает в жизнь принятые решения общего собрания участников (акционеров) и совета директоров общества.

Единоличный исполнительный орган представляет интересы корпорации, вправе заключать различные сделки с контрагентами.

Возлагая на единоличные исполнительные органы функции оперативного управления и руководства деятельностью корпорации, гражданское законодательство предусматривает возложение на данный орган корпоративного управления особых мер ответственности, что служит защите интересов участников корпорации и стабильности ее деятельности.

Действующее законодательство, следует отметить, лишь фрагментарно определяет правовой статус единоличного исполнительного органа корпорации. Ни в ГК РФ, ни в специальных законах, регламентирующих деятельность той или иной организационноправовой формы юридического лица, нет детальной регламентации требований, предъявляемых к единоличному исполнительному 
органу, порядку оформления с ним трудовых отношений и т. д. Это позволяет прийти к выводу, что законодатель подразумевает отнесение данных вопросов на усмотрение корпораций.

Единоличным исполнительным органом может быть не только участник корпорации, но и иное лицо. Так, положениями гражданского законодательства допускается назначение на должность единоличного исполнительного органа гражданина или юридического лица, которые имеют опосредованное отношение к его деятельности. Важнейшее значение в данном аспекте имеет профессионализм и компетентность потенциального кандидата.

Согласно ч. 1 ст. 2 Гражданского кодекса Российской Федерации (часть первая) от 30 ноября 1994 г. № 51-Ф3 [1] (далее - ГК РФ), граждане признаются полноправными участниками регулируемых гражданским законодательством отношений. Гражданское законодательство допускает возможность осуществления гражданином предпринимательской деятельности без образования юридического лица (ч. 1 ст. 23 ГК РФ).

Потенциальным кандидатом может быть индивидуальный предприниматель, который регистрируется в данном качестве для осуществления предпринимательской деятельности. С одной стороны, в России сформирована достаточно обширная нормативная правовая база для осуществления индивидуального предпринимательства, но с другой правовой статус индивидуального предпринимателя в недостаточной степени регламентирован, что порождает различные научные дискуссии относительно его правового положения. По сравнению с юридическим лицом правовое положение индивидуального предпринимателя носит более упрощенный характер осуществления предпринимательской деятельности. В частности, более простым и льготным является порядок налогообложения. Индивидуальный предприниматель вправе свободно использовать финансовые ресурсы и средства, находящиеся в коммерческом обороте, без каких-либо ограничений.

Несмотря на имеющееся внешнее сходство, правовое положение индивидуального предпринимателя отличается от положения юридического лица. Если обратиться к положе- ниям гражданского законодательства, то оно также достаточно ясно разграничивает правовой режим данных участников правоотношений.

Индивидуальный предприниматель обладает определенными преимуществами в качестве единоличного исполнительного органа: имеет опыт в сфере осуществления предпринимательской деятельности, заключения гражданско-правовых договоров; в случае привлечения к ответственности отвечает принадлежащим ему имуществом.

В корпоративных отношениях очень большую роль могут играть личностные качества участников. Так, зачастую важен неизменный состав участников корпорации, которые могут не желать присутствия посторонних лиц в их предпринимательстве, в том числе в должности единоличного исполнительного органа.

Существенные изменения, касающиеся статуса и деятельности корпораций, были внесены в 2014 году. Они затронули, в том числе, вопросы статуса единоличного исполнительного органа. Их сущность сводится к тому, что в юридическом лице, согласно уставным документам, можно учредить несколько единоличных исполнительных органов в одной корпорации. Прежнее законодательство такой возможности не допускало. Данная законодательная новелла была неоднозначным образом воспринята в научной литературе. Сторонники такого решения ссылаются на опыт ряда зарубежных стран, где распространенным является представление интересов юридического лица несколькими руководителями $[4$, с. 10$]$.

C точки зрения интересов участников корпораций данное нововведение может представлять потенциальную привлекательность благодаря возможности обезопасить себя от недобросовестных действий одного руководителя. Однако в российской практике наблюдается совершенно иная ситуация. Как правило, на должности единоличного исполнительного органа назначаются «проверенные» лица, хорошо знакомые с учредителями корпорации и заслуживающие их доверия.

Негативным моментом следует назвать сложности, с которыми могут столкнуться контрагенты юридического лица. Среди них можно назвать неопределенность в понимании действующего единоличного исполнитель- 
ного органа, в проверке его полномочий. К тому же не следует забывать о возможных корпоративных конфликтах между несколькими органами юридического лица. В этой связи более правильной видится позиция тех авторов, которые с опасением и недоверием относятся в внесенным изменениям в ГК РФ, отмечая повышенные риски возникновения корпоративных конфликтов [2, с. 55].

Полагаем, что выбор оптимальной модели корпоративного управления оставлен за учредителями корпорации, которые на основе оценки негативных и отрицательных факторов должны прийти к собственному решению.

Несмотря на то обстоятельство, что компетенция единоличного исполнительного органа юридического лица (в том числе - корпорации) определяется по «остаточному принципу», исходя из первостепенного определения компетенции высшего органа корпорации оставшийся объем полномочий носит достаточный характер.

\section{Ответственность единоличного исполнительного органа}

Единоличный исполнительный орган может быть привлечен к гражданско-правовой ответственности в случае причинения ущерба корпорации.

Несмотря на наличие правовых норм, регламентирующих вопросы ответственности единоличного исполнительного органа корпоративной организации, в судебной практике так и не сформировано единообразного подхода к разрешению корпоративных споров о привлечении единоличного исполнительного органа корпоративной организации к гражданско-правовой ответственности в случае причинения убытков данной корпорации. Такие убытки возможны вследствие ненадлежащего исполнения обязанностей исполнительным органом. Использованные законодателем категории «недобросовестность» и «неразумность», свидетельствующие о противоправном поведении единоличного исполнительного органа, носят оценочный и субъективный характер и рассматриваются судами в каждой ситуации поразному с учетом выяснения конкретных обстоятельств по делу.
Критерии разграничения добросовестного и недобросовестного, разумного и неразумного поведения в гражданском законодательстве не выработаны. Не нашли должного законодательного разрешения и вопросы, связанные с распределением бремени доказывания вины единоличного исполнительного органа корпоративной организации, а также размера причиненного ущерба.

Признаки недобросовестности закреплены в п. 2 Постановления Пленума ВАС РФ от 30 июля 2013 г. № 62 «О некоторых вопросах возмещения убытков лицами, входящими в состав органов юридического лица», среди которых, в частности, указаны: наличие противоречий между личными интересами и интересами юридического лица; сокрытие информации о совершенной сделке; совершение сделки в отсутствие получения на то обязательного согласия юридического лица и т. д.

В одной из реальных ситуаций, как следует из материалов дела, в период с 01.07.2010 по 30.06.2013 единоличным исполнительным органом должника на основании Договора от 01.07.2010 о передаче полномочий единоличного исполнительного органа являлось возглавляемое директором Берлиным Л.А. ЗАО «УК “Колмарпроект”» (06.12.2017 изменено название на $\mathrm{AO}$ «Системпроект», далее - управляющая компания). Суд, удовлетворяя заявленные требования частично, исходил из доказанности неправомерности действий управляющей компании и ее директора Берлина Л.А., повлекших начисление санкций на должника, причинивших ему убытки в размере 1800 469,17 рублей. В связи с невозможностью определения персональной ответственности Наганова К.В. на момент рассмотрения требований, суд выделил требование в отдельное производство. Доначисленные суммы пени и штрафов по решению налогового органа являются убытками должника, причиненными в связи с неправомерными действиями контролирующих должника лиц. Неотвратимость привлечения виновных лиц, в том числе контролирующих должника, к ответственности подтверждается и последующими изменениями законодательства о банкротстве путем введения специальных норм в соответствующий закон. Так, законодатель не только подчеркнул особую значимость ответствен- 
C.B. Мyдрицุкий. Роль единоличного исполнительного органа в деятельности корпорации

ности руководителей должника, но и установил особые условия такой ответственности. Суд апелляционной инстанции учел, что смысл применяемой нормы права извлекается не только путем ее грамматического толкования, но и телеологического (целевого), а также исторического толкования, исходя из динамики развития закона [3].

Действующее законодательство в большей степени ориентировано на закрепление норм об ответственности в отношении обществ и иных субъектов, а не ответственности непосредственно аффилированных лиц, что еще раз подтверждает актуальность вопроса о необходимости разработки и принятия специальных правил об ответственности аффилированных лиц, основанных не только на положениях акционерного права, но и учитывающих сущность и характеристики аффилированных лиц, которые являются особыми субъектами правоотношений.

\section{Выводы}

Правовое регулирование статуса единоличного исполнительного органа носит комплексный характер и осуществляется нормами различных отраслей права - корпоративного и гражданского, что порождает проблему применения той или иной нормы права. Соотнося нормы гражданского и корпоративного права при регулировании отношений с корпоративным управлением, необходимо учитывать, что основу данных правоотношений составляют именно имущественные права и интересы участников, контрагентов корпорации и других лиц, что предполагает их сосредоточение на методах гражданско-правового регулирования. Нормы корпоративного права в своей основе регулируют отношения, связанные с участием в корпоративных организациях или с управлением, но являются разновидностью гражданских правоотношений, согласно ГК РФ. Практика показывает, что привлечение единоличного исполнительного органа к ответственности сопряжено с определенными сложностями, которые во многом обусловлены несовершенством положений действующего законодательства, требующими своего разрешения.

\section{СПИСОК ЛИТЕРАТУРЫ}

1. Гражданский кодекс Российской Федерации (часть первая) от 30.11.1994 г. № 51-Ф3 // Собрание законодательства РФ. - 1994. - № 32. - Ст. 3301.

2. Долинская, В. В. Проблемы корпоративных споров при разработке единого Гражданского процессуального кодекса Российской Федерации / В. В. Долинская // Законы России: опыт, анализ, практика. - 2015. - № 3. - С. 51-57.

3. Постановление Седьмого арбитражного апелляционного суда от 4 декабря 2019 г. № 0740 АП-11639/2017(2)32. - Доступ из справ.-правовой системы «КонсультантПлюс».

4. Суханов, Е. А. Корпоративное соглашение это бомба под весь наш оборот / Е. А. Суханов // Закон. - 2014. - № 7. - С. 8-13.

5. Турбина, И. А. Единоличный исполнительный орган хозяйственного общества в системе корпоративного управления / И. А. Турбина // Legal Concept $=$ Правовая парадигма. -2016 . - № 1. C. $145-150$.

\section{REFERENCES}

1. Grazhdanskiy kodeks Rossiyskoy Federatsii (chast pervaya) ot 30.11.1994 g. № 51-FZ [Civil Code of the Russian Federation (Part One) from November 30, 1994 No. 51-FZ]. Sobranie zakonodatelstva RF [Collection of Legislation of the Russian Federation], 1994, no. 32, art. 3301.

2. Dolinskaya V.V. Problemy korporativnykh sporov pri razrabotke edinogo Grazhdanskogo protsessualnogo kodeksa Rossiyskoy Federatsii [Problems of Corporate Disputes in the Development of a Unified Civil Procedural Code of the Russian Federation]. Zakony Rossii: opyt, analiz, praktika [Laws of Russia: Experience, Analysis, Practice], 2015, no. 3, pp. 51-57.

3. Postanovlenie Sedmogo arbitrazhnogo apellyatsionnogo suda ot 4 dekabrya 2019 g. № 0740 AP-11639/2017(2)32 [Resolution of the Seventh Arbitration Court of Appeal of December 4, 2019 No. 0740 AP-11639/2017(2)32]. Access from Reference Legal System 'KonsultantPlyus'.

4. Sukhanov E.A. Korporativnoe soglashenieeto bomba pod ves nash oborot [Corporate Agreement is a Bomb for All Our Turnover]. Zakon [Law], 2014, no. 7 , pp. 8-13.

5. Turbina I.A. Edinolichnyy ispolnitelnyy organ khozyaystvennogo obshchestva $\mathrm{v}$ sisteme korporativnogo upravleniya [Single Executive Body of a Business Company in the System of Corporative Management]. Legal Concept, 2016, no. 1 , pp. 145-150. 


\section{ВОПРОСЫ ЧАСТНОПРАВОВОГО РЕГУЛИРОВАНИЯ}

\section{Information About the Author}

Sergey V. Mudritsky, Postgraduate Student, Department of Civil Law Disciplines, Volgograd Institute of Management - Branch of the Russian Presidential Academy of National Economy and Public Administration, Gagarina St, 8, 400131 Volgograd, Russian Federation, mudritsky.sv@gmail.com, https://orcid.org/0000-0001-5311-7526

\section{Информация об авторе}

Сергей Васильевич Мудрицкий, аспирант кафедры гражданско-правовых дисциплин, Волгоградский институт управления - филиал Российской академии народного хозяйства и государственной службы при Президенте РФ, ул. Гагарина, 8, 400131 г. Волгоград, Российская Федерация, mudritsky.sv@gmail.com, https://orcid.org/0000-0001-5311-7526 